BISMA

(Bisnis dan Manajemen)
Volume 11, Nomor 1, Oktober 2018, 47-66

ISSN 2549-7790 (Online)

ISSN 1979-7192 (Print)

https://journal.unesa.ac.id/index.php/bisma/index

\title{
Analisis Pengaruh Permodalan, Pemasaran, Teknologi \& Inovasi, Kecerdasan Spiritual, dan Perencanaan Strategi terhadap Kinerja Usaha Kecil Menengah (UKM) Mebel di Klaten Jawa Tengah
}

\author{
Lasminiasih $^{1}$, Rooswhan Budhi Utomo ${ }^{2}$, Sigit Nur Dianto ${ }^{3}$ \\ Universitas Gunadarma ${ }^{1,2,3}$ \\ Email korespondensi: lasminiasih@staff.gunadarma.ac.id
}

\begin{abstract}
Small medium enterprises (SMEs) constitute a business activity that is able to expand employment and provide economic services broadly to society and can play a role in the process of Equalization and the increase in people's income, encouraging the growth of economy and play a role in realizing stability nationwide. The purpose of this research is to know the influence of the capital, marketing, technology and innovation, spiritual intelligence and planning strategy on performance of small medium-sized enterprise (SMEs) furniture in Klaten, Central Java. The object of the research done in the village of Dayan, Ceper, Klaten, Central Java. The methods used in this research are multiple linear regression by disseminating a questionnaire in directly. The results showed that capital, marketing, technology and innovation, spiritual intelligence and planning strategy of the influence on the performance of small and medium businesses (SMEs) furniture in the Klaten.
\end{abstract}

Keywords: business furniture; finance; innovation small and medium businesses (SMEs); marketing; technology

Received: 26 Januari 2018 Reviewed: 21 Pebruari 2018

Accepted: 18 April 2018

Published: 31 Oktober 2018

\section{PENDAHULUAN}

UMKM adalah jenis usaha paling banyak ditemui di Indonesia. Hampir 99\% dari seluruh perusahaan di Indonesia masuk kategori UMKM. Kebanyakan usaha kecil ini terkonsentrasi pada sektor perdagangan, pangan, olahan pangan. Tekstil dan garmen, kayu dan produk kayu serta produksi mineral non migas. UMKM merupakan sumber utama lapangan pekerjaan dan penopang 
pertumbuhan ekonomi di Indonesia. UMKM memberikan kontribusi terhadap ketahanan perekonomian pada masa krisis tahun 2008-2009. Data BPS tahun 2014 menunjukkan bahwa umkm berkontribusi dalam membuka kesempatan kerja sebesar 96.9\%, berkontribusi terhadap pembentuka PDB sebesar $60.4 \%$, juga berkontribusi pada penerimaan ekspor sebesar 27.700 milyar atau 4,8\% dari total ekspor. Sayangnya sebanyak 91\% UMKM melakukan ekspor melalui pihak ketiga atau pedagang perantara (broker), hanya $8.8 \%$ yang berhubungan langsung dengan pembeli dari luar negeri. (Christea dan Mukhlis, 2016). Meskipun perkembangan UMKM sedemikian pesat namun rendahnya produktivitas masih menjadi permasalahan utama yang dihadapi. Menurut Emma Dwi Ratnasari (2016) masalah internal yang seringkali dihadapi oleh UMKM yaitu: rendahnya kualitas SDM, penguasaan teknologi dan pemasaran, terbatasnya akses UMKM terhadap permodalan, informasi, serta faktor produksi lainnya.

Hadiyati (2010) menyatakan bahwa, survei dari BPS mengidentifikasikan berbagai kelemahan dan permasalahan yang dihadapi UMKM berdasarkan prioritasnya, yaitu meliputi kurangnya permodalan, kesulitan dalam pemasaran, persaingan usaha yang ketat, kesulitan bahan baku, kurang teknis produksi dan keahlian, kurangnya keterampilan manajerial (SDM), dan kurangnya pengetahuan dalam masalah manajemen khususnya bidang keuangan dan akuntansi. Di sisi lain, era MEA tahun 2016 lalu merupakan tantangan bagi para pelaku UKM. Selama ini UMKM di Indonesia lebih fokus untuk melayani pasar domestik dibandingkan dengan mencari peluang ekspor (Mukhlis dkk, 2016). Namun demikian pasar domestik pun akan semakin ketat dengan hadirnya produk-produk pesaing dari negara tetangga sehingga UMKM pun harus dapat meningkatkan daya saingnya.

Pemasaran merupakan salah satu kegiatan pokok yang dilakukan oleh para pengusaha dalam usahanya untuk mempertahankan kelangsungan hidup perusahaan dan perkembangan usahanya serta untuk dapat memenangkan persaingan. Berhasil tidaknya dalam pencapaian tujuan tersebut tergantung pada kemampuan dan keahlian di bidang pemasaran (Purwanti, 2012). Sejalan dengan perubahan lingkungan yang begitu cepat, diperlukan perencanaan strategi agar dapat menciptakan daya saing yang tinggi untuk mencapai keberhasilan usaha. Supratikno et al (2003) mengemukakan kaitan antara strategi dan kinerja bisnis, dimana terdapat korelasi positif antar perencanaan strategi dengan kinerja usaha. Dengan adanya perencanaan strategis akan dapat menempatkan perusahaan secara optimal di dalam lingkungan persaingan dan mampu melakukan antisipasi terhadap perubahan lingkungan yang sering kali tidak dapat diduga (Pearce dan Robinson, 2003). Selain perencanaan strategis untuk menghadapi perubahan lingkungan tadi, faktor kecerdasan dari pengusaha juga memegang peranan yang sangat penting bagi kesuksesan UMKM. Kecerdasan secara umum diartikan 
sebagai kemampuan untuk berpikir, merencanakan, menciptakan, menyesuaikan, bereaksi, mengambil keputusan dan belajar (Nobel, 2000).

Zohar \& Marshal (2001) menyebutkan bahwa terdapat tiga kecerdasan dasar yaitu kecerdasan intelektual, kecerdasan emosional dan kecerdasan spiritual. Jika kecerdasan rasional adalah tentang berpikir dan memecahkan masalah logis, kecerdasan emosional adalah kesepakatan dengan perasaan dan memungkinkan kita menilai situasinya, maka kecerdasan spiritual adalah tentang menjawab pertanyaan apakah kita ingin berada dalam situasi sekarang (Kadkhoda dan Jahani, 2012). Kecerdasan spiritual merupakan kecerdasan inti yang menggambarkan kemampuan untuk memecahkan masalah yang berhubungan dengan nilai, visi, dan arti (Zohar \& Marshal, 2001). Dengan demikian kecerdasan spiritual sangat berarti bagi kesuksesan UMKM. Teknologi dan inovasi pun juga memainkan peranan penting untuk dapat memenangkan persaingan usaha di era global ini. Menurut Adeosun (2009), penggunaan TI memberikan nilai positif bagi strategi manajemen yang terkait dengan aspek komunikasi, akses informasi, pengambilan keputusan, manajemen data dan knowledge management pada sebuah organisasi.

Agar dapat menggunakan teknologi terkini dan berinovasi dibutuhkan biaya yang tidak sedikit sehingga akses sumber permodalan menjadi isu yang penting bagi mereka untuk melakukan ekspansi usaha. Hal senada diungkapkan oleh Beck dan Demirguc-Kunt (2006) yang berpendapat bahwa akses ke sumber permodalan membuat UMKM dapat melakukan investasi produktif untuk memperluas bisnis mereka dan untuk memperoleh teknologi terbaru, sehingga memastikan daya saing mereka, dan mendorong inovasi, ketahanan ekonomi makro dan pertumbuhan PDB. Usaha kecil menengah (UKM) merupakan sumber utama terciptanya lapangan pekerjaan, kemajuan teknologi, dan sebagai tolak ukur untuk keunggulan negara maju dan berkembang. Karena tekanan persaingan yang semakin ketat dan kebutuhan untuk memasuki pasar global yang dialami oleh UKM, bisnis ini secara bertahap menggunakan Teknologi Informasi untuk mengambil keuntungan yang lebih besar.( Sabouri, Hong, \& Zulkifli, 2011).

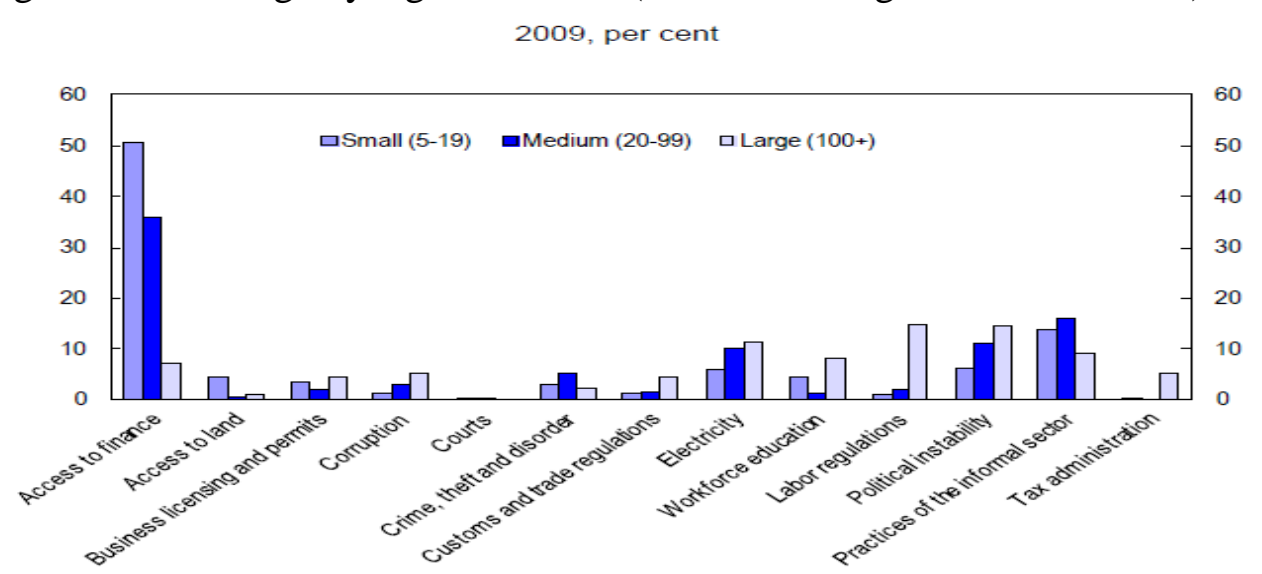

Gambar 1. Hambatan Utama untuk Berinvestasi menurut Ukuran Perusahaan 


\section{UMKM}

Menurut Bab 1 mengenai ketentuan umum dalam Undang-Undang Republik Indonesia tentang UMKM, usaha mikro adalah usaha produktif yang dimiliki perorangan dan/ atau badan usaha perorangan yang memenuhi kriteria usaha mikro sebagaimana yag diatur dalam Undang-Undang tersebut dan memiliki kekayaan bersih maksimal 50 juta tidak termasuk tanah dan bangunan tempat usaha atau memiliki hasil penjualan tahunan maksimal 300 juta. Usaha kecil adalah usaha ekonomi produktif yang berdiri sendiri, yang dilakukan oleh perorangan atau badan usaha yang bukan merupakan anak perusahaan atau bukan cabang perusahaan yang dimiliki, dikuasai, atau menjadi bagian langsung maupun tidak langsung dari usaha menengah atau usaha besar yang memenuhi kriteria usaha kecil sebagaimana dimaksud didalam Undang-Undang tersebut dan memiliki kekayaan bersih lebih dari 50 juta sampai maksimal 500 juta tidak termasuk tanah dan bangunan tempat usaha serta memiliki hasil penjualan tahunan melebihi 300 juta sampai 2.5 milyar. Sedangkan definisi dari usaha menengah yaitu usaha ekonomi produktif yang berdiri sendiri, yang dilakukan oleh perorangan atau badan usaha yang bukan merupakan anak perusahaan atau cabang perusahaan yang dimiliki, dikuasai, atau menjadi bagian langsung maupun tidak langsung dengan usaha kecil atau usaha besar dengan jumlah kekayaan bersih atau hasil penjualan tahunan sebagaimana diatur dalam Undang-Undang tersebut dan memiliki kekayaan bersih lebih dari 500 juta sampai 10 milyar tidak termasuk tanah dan bangunan tempat usaha serta memiliki hasil penjualan tahunan melebihi 2.5 milyar sampai maksimal sebesar 50 milyar.

Selain itu, definisi UMKM menurut BPS berdasarkan tenaga kerja. Usaha mikro adalah unit usaha dengan jumlah pekerja tetap maksimal 4 orang, usaha kecil dari 5 sampai 9 orang pekerja dan usaha menengah dari 20 sampai 99 orang pekerja. Sedangkan Bank Indonesia (BI) mendefinisikan UMKM dengan dua kriteria. Kriteria yang pertama berdasarkan aset, omset, dan badan hukum. Kriteria yang kedua berdasarkan kredit yang diterima oleh pengusaha. Usaha mikro adalah usaha yang dapat menerima kredit hingga Rp 50 juta. Sedangkan usaha kecil adalah usaha yang dapat menerima kredit mulai dari Rp 50 juta hingga Rp 500 juta. Lalu usaha menengah adalah usaha yang dapat menerima kredit dari Rp 500 juta sampai Rp 5 miliar. Walaupun usaha mikro kecil menengah telah menunjukkan peranannya dalam perekonomian nasional namun masih menghadapi berbagai hambatan dan kendala. Beragamnya hambatan dan kendala yang dihadapi UMKM, tampaknya masalah permodalan masih merupakan salah satu faktor kritis bagi UMKM, baik untuk pemenuhan kebutuhan modal kerja maupun modal investasi dalam pengembangan usaha. 


\section{Teknologi dan Inovasi}

Inovasi dan teknologi sangat bermanfaat bagi sebuah perusahaan tidak hanya dari satu sisi, namun dari banyak sisi. Teknologi baru memungkinkan perusahaan dapat meminimalisir biaya dan menaikkan kuantitas produksi yang pada akhirnya akan dapat meningkatkan daya saing. Di sisi lain teknologi baru dapat menyebarkan lebih banyak informasi pada calon konsumen yang akhirnya dapat meningkatkan permintaan. Menurut Larsen dan Lewis (2007), karakter yang penting dalam wirausahawan adalah kemampuan berinovasi. Dalam menjalankan suatu usaha perusahaan tidak akan bertahan apabila tanpa di imbangi dengan adanya suatu inovasi. Hal tersebut disebabkan karena adanya kebutuhan, keinginan dan permintaan,pelanggan yang selalu berubah-ubah. Wahyono (2002) menjelaskan bahwa inovasi yang berkelanjutan dalam suatu perusahaan merupakan kebutuhan dasar yang pada gilirannya akan mengarah pada terciptanya keunggulan kompetitif.

Menurut Hendro (2011), inovasi dapat dibedakan menjadi beberapa macam, di antara sebagai berikut. (1) Inovasi produk, yaitu inovasi yang dilakukan pada isi produk (rasa, kualitas) atau kemasan (pembungkus, tulisan, warna, bentuk). (2) Inovasi marketing, yaitu inovasi yang dilakukan pada cara penjualan, distribusi atau pengiklanannya. (3) Inovasi proses, yaitu inovasi yang dilakukan pada proses penciptaan produk, proses produksi, proses pengemasan, proses riset dan pengembangan atau proses penciptaan mesin baru. (4) Inovasi teknikal, yaitu inovasi yang dilakukan pada teknik desain, teknik pengerjaan atau teknik pengawasannya. (5) Inovasi administrasi, yaitu inovasi yang dilakukan pada penyimpanan data atau pada pembuatan dan pengumpulan data. Sedangkan, Rademaker (2005) membagi inovasi ke dalam beberapa tipe yaitu sebagai berikut. (1) Inovasi produk, merupakan inovasi produk yang relative baru bagi suatu industry yang dihasilkan dengan teknologi informasi yang di miliki perusahaan saat ini. (2) Inovasi proses, merupakan peningkatan dan pembaharuan metode produksi yang akan mendorong pengurangan dalam unit biaya produksi. Inovasi Proses menekankan pada metode-metode baru dalam pengoperasian dengan cara membuat teknologi baru atau mengembangkan teknologi yang ada. (3) Inovasi organisasi merupakan adopsi gagasan atau perilaku baru dalam organisasi. Inovasi organisasi adalah suatu proses yang diawali dengan kegiatan penemuan ide-ide baru yang diimplementasikan dalam bentuk produk baru, proses baru dan system administrasi baru yang dapat menciptakan nilai unggul bagi perusahaan.

Hermana (2006) membagi ukuran inovasi dalam dua kelompok yaitu ukuran yang berhubungan dengan output dan input. Ukuran inovasi dilihat dari outputnya meliputi produk atau proses baru yang dikembangkan, persentasi penjualan dari produk atau proses baru tersebut, kekayaan intelektual yang dihasilkan, kinerja perusahaan. Sedangkan ukuran inovasi yang berkaitan dengan input adalah 
investasi dibidang penelitian dan pengembangan, kekayaan intelektual, biaya akuisisi teknologi baru, biaya produksi pertama produk baru, asset tak berwujud seperti goodwill, biaya pemasaran dan pelatihan untuk produk baru, perubahan organisasi, dan metode manajerial. Terbatasnya akses terhadap informasi terkait kemajuan ilmu pengetahuan dan teknologi menyebabkan sarana dan prasarana yang dimiliki tidak bisa berkembang mengikuti kemajuan usaha yang diharapkan. Keterbelakangan teknologi ini tidak hanya membuat rendahnya total factor productivity dan efisiensi di dalam proses produksi, tetapi juga rendahnya kualitas produk yang dibuat.

\section{Pemasaran}

Pemasaran merupakan salah satu kegiatan pokok yang dilakukan oleh para pengusaha dalam usahanya untuk mempertahankan kelangsungan hidup perusahaan dan perkembangan usahanya serta untuk mendapatkan laba. Berhasil tidaknya dalam pencapaian tujuan tergantung pada kemampuan dan keahlian di bidang pemasaran (Purwanti, 2012). Banyak definisi pemasaran yang diberikan oleh para ahli. Salah satuya adalah definisi menurut Kotler (2000) yang menyebutkan bahwa Pemasaran adalah suatu proses sosial dan manajerial yang didalamnya individu dan kelompok mendapatkan apa yang mereka butuhkan dan inginkan dengan menciptakan, menawarkan, dan mempertukarkan prosuk yang bernilai kepada pihak lain. Swastha dan Irawan (2008:29) menyatakan bahwa pemasaran sebagai sebuah disiplin ilmu pengetahuan yang berupaya meletakkan asumsi-asumsi yang dapat digunakan dalam menciptakan nilai optimal bagi stakeholders dari waktu ke waktu. Ketika perubahan nilai terjadi, konsep pemasaran akan berubah sesuai dengan perubahan tuntutan stakeholders dan perkembangan pasar.

Menurut Pribadi dan Mundung (2007:26), konsep pemasaran mengandung tiga unsur pokok yaitu sebagai berikut. (a) Mengarahkan usaha kepada pelayanan keperluan konsumen yang dilayani (menyediakan/ menemukan barang yang diperlukan). (b) Melaksanakan kegiatan pemasaran yang terpadu dalam usaha mempengaruhi pasar untuk merebut konsumen. (c) Mewujudkan kepuasan konsumen dalam upaya menciptakan pelanggan tetap. Manajemen pemasaran dikelompokkan dalam empat aspek yang sering dikenal dengan marketing mix atau bauran pemasaran. Menurut Kotler dan Armstrong (2004:78), bauran pemasaran (marketing mix) adalah kumpulan alat pemasaran taktis terkendali yang dipadukan perusahaan untuk menghasilkan respon yang diinginkannya di pasar sasaran. Bauran pemasaran terdiri dari empat kelompok variabel yang disebut "empat P", yaitu sebagai berikut. (1) Product (produk), adalah kombinasi barang dan jasa yang ditawarkan perusahaan kepada pasar sasaran. (2) Price (harga), merupakan sejumlah uang yang harus dibayarkan pelanggan untuk memperoleh produk. Harga adalah satu-satunya unsur bauran pemasaran yang 
menghasilkan pendapatan, sedangkan unsur-unsur lainnya menghasilkan biaya. (3) Place (tempat), yaitu saluran pemasaran yang meliputi kegiatan perusahaan untuk membuat produk tersedia bagi pelanggan sasaran. (4) Promotion (promosi), yaitu aktivitas untuk menyampaikan produk dan membujuk pelanggan untuk membelinya.

\section{Permodalan}

Untuk melakukan kegiatan usaha mutlak diperlukan modal usaha, sumber modal usaha ini dapat diperoleh dari modal sendiri, lembaga keuangan (bank maupun non-bank), bantuan pemerintah, dan lain-lain. Beberapa penelitian terdahulu menyebutkan bahwa struktur modal UKM khususnya di Indonesia, hampir sebagian besar berasal dari modal sendiri. Sangat sedikit, mereka yang berhubungan dengan pihak ketiga untuk mendapatkan dana. Jika mereka membutuhkan suntikan dana dari pihak luar, justru pihak-pihak penyedia dana selain bank, yang sangat berperan. Misal bank-bank perkreditan rakyat atau malah rentenir. Hal tersebut terjadi karena banyak hal antara lain: lokasi bank yang terlalu jauh bagi banyak pengusaha yang tinggal di daerah yang relatif terisolasi, persyaratan terlalu berat, urusan administrasi terlalu berteletele, dan kurang informasi mengenai skim-skim perkreditan yang ada dan prosedur. (Sakur, 2011). Usaha mikro, khususnya di Indonesia seringkali menghadapai dua masalah utama dalam aspek finansial yaitu mobilisasi modal awal (star-up capital) dan akses ke modal kerja. Kendala ini disebabkan karena lokasi bank yang terlalu jauh bagi banyak pengusaha yang tinggal di daerah yang relatif terisolasi, persyaratan terlalu berat, urusan administrasi terlalu berteletele, dan kurang informasi mengenai skim-skim perkreditan yang ada dan prosedur.

Setidaknya ada tiga jenis modal yang diperlukan, yaitu modal investasi, modal kerja dan modal operasional (Sugiono, 2015). Setiap perusahaan selalu membutuhkan modal kerja untuk membiayai operasinya setiap hari, misalnya membayarkan gaji karyawan, pembelanjaan bahan mentah dan membayar upah buruh. Modal kerja adalah modal yang harus kita keluarkan untuk membeli atau membuat barang dan jasa yang dihasilkan. Modal kerja bisa dikeluarkan setiap bulan atau setiap ada permintaan. (Suharyadi, 2007). Menurut Jumingan (2011) menyebutkan bahwa modal kerja hanyalah jumlah dana yang dipergunakan selama satu periode akuntansi yang dimaksudkan untuk menghasilkan pendapatan jangka pendek saja, yaitu berupa kas, persediaan barang dagang, piutang (setelah dikurangi profit margin) dan pernyusutan aktiva tetap.

\section{Kecerdasan Spiritual}

Kecerdasan Spiritual membuat seorang wirausahawan menjadi rendah diri dan tidak sombong meski telah sukses, tetap jujur, percaya dan memperhatikan orang-orang di sekitar mereka. Kecerdasan Spiritual memunculkan nilai lebih dari 
seorang wirausahawan yang membuat mereka menonjol dari yang lain. Menurut George (2006), kecerdasan spiritual penting untuk membantu seseorang dalam menemukan kekuatan dirinya yang paling dalam dan juga kemampuan untuk peduli, bertoleransi dan beradaptasi terhadap lingkungannya. Untuk itu, kecerdasan spiritual perlu ada di dalam diri seseorang dalam meraih kesuksesan. Kesadaran bahwa hidup manusia ada yang mengatur, dapat memberikan power cukup besar yang berpengaruh kepada manusia dalam kondisi apapun, baik kondisi normal maupun kondisi pada saat manusia dihadapkan pada masalahmasalah kehidupan.

Secara umum ada enam manfaat bagi perusahaan yang menyandarkan bisnisnya pada aspek spiritualitas. Pertama, perusahaan akan jauh dari berbagai kecurangan (fraud) yang mungkin terjadi akibat 'menghalalkan segala cara' karena dari sinilah kebangkrutan suatu usaha dimulai. Kedua, meningkatnya produktivitas dan kinerja perusahaan. Ketiga, terbangunnya suasana kerja yang harmonis. Keempat, meningkatnya citra positif perusahaan. Kelima, perusahaan menjadi tumbuh dan berkembang secara berkesinambungan (sustainable company). Keenam, menurunkan perpindahan karyawan. Mccormick (1994, 20) dan Mitroff and Denton (1999, 111), dalam penelitiannya membedakan kecerdasan spriritual dengan religiusitas di dalam lingkungan kerja. Religiusitas lebih ditujukan pada hubungannya dengan Tuhan sedangkan kecerdasan spiritual lebih terfokus pada suatu hubungan yang dalam dan terikat antara manusia dengan sekitarnya secara luas

\section{Perencanaan Strategi}

Perencanaan strategis adalah serangkaian proses yang dilakukan untuk mengembangkan suatu strategi yang akan berkontribusi untuk mencapai arah / tujuan organisasi. Ada lima langkah umum dalam proses perencanaan strategis: tujuan / penetapan tujuan, analisis situasi, alternative pertimbangan, implementasi dan evaluasi (Crittenden dan Crittenden, 2000). Sayangnya, sampai saat ini, hanya sedikit peneliti yang menangani proses pembuatan strategi perusahaan kecil dan menengah Noble (1999) berpendapat bahwa penerapan strategi perencanaan strategis yang tidak efektif di banyak perusahaan merupakan alasan utama kegagalan mencapai kinerja yang diharapkan atau yang diproyeksikan. Perencanaan strategis terdiri dari proses perencanaan yang dilakukan di perusahaan dalam mengembangkan strategi yang mungkin berkontribusi terhadap kinerja (Tapinos et al., 2005). Perencanaan strategis dapat meningkatkan kinerja dengan menghasilkan informasi yang relevan, dan menciptakan pemahaman yang lebih baik mengenai lingkungan sekitar, dan juga mengurangi ketidakpastian (Hodgetts dan Kuratko, 2001).

Perencanaan di perusahaan kecil jarang didukung oleh instrument perencanaan yang benar, sebagian besar responden melaporkan bahwa mereka 
merencanakan secara intuitif, dan tidak menggunakan instrumen perencanaan (Stonehouse dan Pemberton, 2002). Dalam melakukan perencanaan strategi ada beberapa hal yang perlu dilakukan yaitu: (a) membuat visi misi dan tujuan yang akan dicapai dalam jangka waktu tertentu, (b) menganalisis lingkungan perusahaan untuk mengetahui peluang dan ancaman yang mungkin terjadi, dan (c) menciptakan system umpan balik untuk mengetahui efektifitas pencapaian implementasi perencanaan strategic. Sedangkan menurut Allison, Kaye, 2005 perencanaan strategik adalah proses sistematik yang disepakati organisasi dan membangun keterlibatan diantara stakeholder utama tentang prioritas yang hakiki bagi misinya dan tanggap terhadap lingkungan operasi. Adapun lima tahapan yang saling berhubungan di dalam penyusunan perencanaan strategis (Thompson dan Strickland 2001, h.6), adalah membentuk visi strategis, menetapkan tujuan, membuat strategi untuk mencapai hasil yang diinginkan, menerapkan dan melaksanakan strategi yang dipilih secara efisien dan efektif, serta mengevaluasi kinerja.

\section{METODE PENELITIAN}

Penelitian ini menggunakan analisis regresi berganda untuk mengetahui pengaruh antara variable dependen dan independen. Lima variabel independen yang digunakan yaitu, permodalan, pemasaran, teknologi dan inovasi, kecerdasan spiritual, perencanaan strategi. Sedangkan variable dependen yang digunakan adalah kinerja usaha.

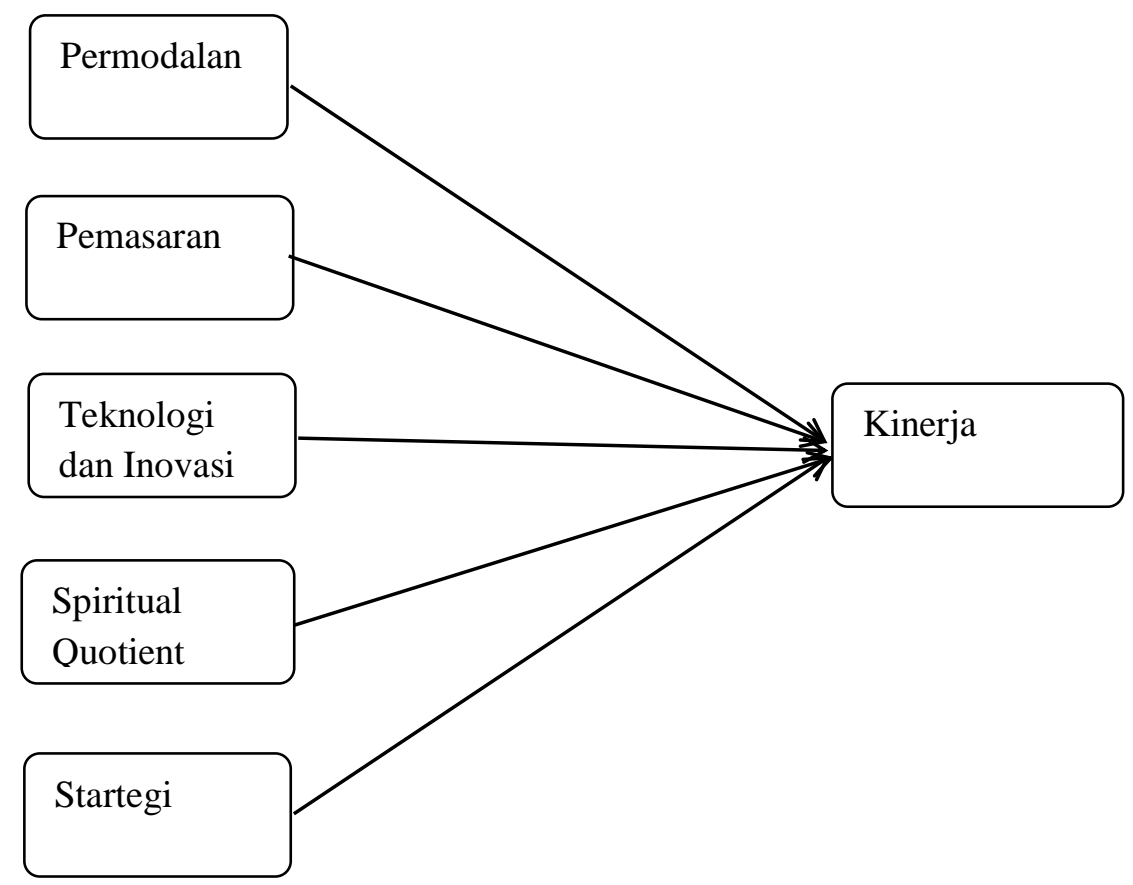

Sumber: data diolah penulis.

Gambar 2. Model Penelitian 
Instrumen penelitian menggunakan kuesioner terstruktur yang terdiri dari dua bagian. Bagian pertama memfokuskan pada karakteristik demografis populasi seperti usia, jenis kelamin, status perkawinan, dan tingkat pendidikan. Bagian kedua berisi pernyataan mengenai keenam variable (permodalan, pemasaran, teknologi dan inovasi, kecerdasan spiritual, perencanaan strategi dan kinerja usaha). Setiap pernyataan diukur pada skala Likert lima poin (mulai dari $1=$ sangat tidak setuju hingga $5=$ sangat setuju).

Kuesioner tersebut kemudian disebarkan kepada 82 perajin mebel di daerah juwiring kabupaten klaten. Diantara 82 kuesioner yang disebarkan, kami menerima kuesioner yang terisi sebanyak 63 kuesioner. Dari 63 kuesioner yang terisi tersebut terdapat 8 kuesioner yang tidak valid, sehingga hanya 55 kuesioner yang dapat kami olah.

\section{HASIL DAN PEMBAHASAN}

Dari hasil secara keseluruhan penyebaran kuisioner yang dilakukan oleh peneliti, terdapat 55 responden yang telah mengisi kuisioner. Kuisioner disebar secara langsung, yang ditujukan kepada UKM mebel di daerah Klaten Jawa Tengah. Model yang digunakan dalam penelitian ini adalah analisis regresi linear berganda. Setelah dilakukan analisis dan pengambilan sampel data dengan variabel Permodalan, Pemasaran, Teknologi dan Inovasi, Spiritual Quotient dan Strategi terhadap Kinerja kemudian data diolah menggunakan software SPSS 20 maka dapat dihasilkan penjelasan sebagai berikut.

\section{Uji Regresi Linear Berganda}

Analisis regresi linier digunakan untuk mengetahui pengaruh antara variabel dependen yaitu permodalan, pemasaran, teknologi dan inovasi, spiritual quotient dengan variabel independen yaitu kinerja. Berdasarkan hasil pengolahan data dengan menggunakan program SPSS 20, maka hasil analisis tampak pada tabel 1.1 berikut:

Tabel 1. Hasil Perhitungan Regresi Linier Berganda

\begin{tabular}{|c|c|c|c|c|c|c|}
\hline \multicolumn{7}{|c|}{ Coefficients } \\
\hline & \multirow[t]{2}{*}{ Model } & \multicolumn{2}{|c|}{ Unstandardized Coefficients } & \multirow{2}{*}{$\begin{array}{c}\begin{array}{c}\text { Standardized } \\
\text { Coefficients }\end{array} \\
\text { Beta }\end{array}$} & \multirow[t]{2}{*}{$\mathrm{T}$} & \multirow[t]{2}{*}{ Sig. } \\
\hline & & B & Std. Error & & & \\
\hline \multirow[t]{6}{*}{1} & (Constant) & .372 & .319 & & 1.165 & .258 \\
\hline & SQ & 1.052 & .227 & .999 & 4.631 & .000 \\
\hline & Strategi & -1.433 & .448 & -1.590 & -3.199 & .005 \\
\hline & Teknologi & 1.544 & .421 & 1.713 & 3.669 & .002 \\
\hline & Permodalan & -1.055 & .188 & -1.378 & -5.625 & .000 \\
\hline & Pemasaran & .768 & .136 & 1.053 & 5.637 & .000 \\
\hline
\end{tabular}

Sumber: Hasil SPSS, data diolah penulis. 
Berdasarkan tabel 1 di atas dapat diperoleh persamaan regresi linear berganda (1) sebagai berikut.

$$
\mathrm{Y}=0,372+1,052 \mathrm{X} 1-1,433 \mathrm{X} 2+1,544 \mathrm{X} 3-1,055 \mathrm{X} 4+0,768 \mathrm{X} 5 \text {. }
$$

\section{Uji Asumsi Klasik}

\begin{tabular}{|c|c|c|}
\hline \multirow[t]{2}{*}{ Variabel } & \multicolumn{2}{|c|}{ Collinearity } \\
\hline & Tolerance & VIF \\
\hline Spiritual Quotient & 0.174 & 5.744 \\
\hline Teknologi & 0.202 & 4.939 \\
\hline Keuangan & 0.122 & 8.164 \\
\hline Pemasaran & 0.211 & 4.743 \\
\hline Asymp. & & 0.812 \\
\hline
\end{tabular}

Sumber: Hasil SPSS, data diolah penulis.

Uji asumsi klasik merupakan uji yang digunakan untuk mengetahui apakah model regresi yang diperoleh dapat menghasilkan estimator yang baik. Berkaitan dengan uji asumsi klasik dalam penelitian ini, model analisis yang digunakan akan menghasilkan estimator yang tidak bias apabila telah memenuhi beberapa asumsi klasik sebagai berikut.

\section{Uji Normalitas}

Uji normalitas merupakan uji yang digunakan untuk menguji apakah dalam analisis regresi antara variabel dependen dan variabel independen mempunyai distribusi normal atau tidak normal. Uji normalitas yang dilakukan pada penelitian ini menggunakan uji normalitas dengan metode Kolmogorov-Smirnov. Pada hasil yang dinyatakan dalam tabel 2, uji normalitas dapat dilihat pada kolom Asymp. $K$ $S$. Dari data diatas menunjukkan besarnya nilai Asymp. K-S adalah 0.812 dan hasil ini menyatakan bahwa nilai dari uji normalitas $>0.05$. Hal ini berarti bahwa data terdistribusi normal dan dapat digunakan dalam penelitian.

\section{Uji Multikolinearitas}

Uji multikolinearitas adalah suatu keadaan dimana antara dua variabel independen atau lebih pada model regresi terjadi hubungan linear yang sempurna atau mendekati sempurna. Pengujian multikolinearitas dilakukan untuk menguji apakah dalam model regresi ditemukan adanya korelasi antar variabel independen. Jika terjadi korelasi, maka dinamakan terdapat problem multikolinearitas. Model regresi yang baik seharusnya tidak terjadi korelasi diantara variabel independen. Untuk mendeteksi adanya multikolinearitas dapat dilakukan dengan melihat tingkat variance inflation factor (VIF) dan nilai telerance. Nilai yang digunakan adalah 0,10 atau sama dengan VIF 10. Jika nilai tolerance lebih besar dari 0,1 dan VIF lebih kecil dari 10 maka variabel bebas tersebut tidak multikolinearitas antar variabel bebas. Dengan demikian model regresi tidak terjadi masalah multikolinearitas. Pada hasil yang dinyatakan dalam tabel 2, maka terlihat bahwa 
nilai tolerance dan nilai VIF menunjukkan tidak ada satu variabel bebas yang memiliki nilai VIF lebih dari 10 dan nilai tolerance kurang dari 0,10. Hasil ini menandakan bahwa tidak terjadi multikolinearitas pada data.

\section{Uji Heteroskedastisitas}

Uji heteroskedastisitas adalah suatu keadaan dimana terjadinya ketidaksamaan varian dari residual pada model regresi. Uji heteroskedastisitas bertujuan untuk menguji apakah dalam sebuah model regresi terjadi ketidaksamaan varians dari residual dari satu pengamatan ke pengamatan yang lain. Uji heteroskedastisitas penelitian ini diuji dengan menggunakan uji gletjer. Hasil pengujian tersebut dapat dilihat dari output regresi table 3 sebagai berikut.

Tabel 3. Uji Heteroskedastisitas

\begin{tabular}{|c|c|c|c|c|c|c|c|}
\hline \multirow{2}{*}{\multicolumn{2}{|c|}{ Model }} & \multicolumn{2}{|c|}{$\begin{array}{c}\text { Unstandardized } \\
\text { Coefficients }\end{array}$} & \multirow{2}{*}{$\begin{array}{c}\begin{array}{c}\text { Standardized } \\
\text { Coefficients }\end{array} \\
\text { Beta } \\
\end{array}$} & \multirow[t]{2}{*}{ t } & \multirow[t]{2}{*}{ Sig. } & \multirow{2}{*}{$\begin{array}{c}\text { Fraction } \\
\text { Missing } \\
\text { Info. }\end{array}$} \\
\hline & & B & Std. Error & & & & \\
\hline \multirow[t]{6}{*}{1} & (Constant) & .273 & .185 & & 1.474 & .157 & \\
\hline & SQ & -.047 & .132 & -.191 & -.359 & .724 & \\
\hline & Strategi & -.320 & .260 & -1.509 & -231 & .233 & \\
\hline & Teknologi & .344 & .244 & 1.623 & 1.409 & .175 & \\
\hline & Keuangan & .010 & .109 & .057 & .094 & .926 & \\
\hline & Pemasaran & -.035 & .079 & -.207 & -.449 & .659 & \\
\hline
\end{tabular}

Sumber: Hasil SPSS, data diolah penulis.

Dari hasil uji tersebut diketahui bahwa nilai signifikasnsi (sig.) hasil korelasi setiap variabel dalam model regresi lebih besar dari 0,05 (5\%). Maka dapat disimpulkan dengan tingkat keyakinan 95\% model regresi dalam penelitian ini baik dengan variabel dependen $(\mathrm{Y})=$ kinerja UKM telah bebas dari asumsi heteroskedastisitas.. Dan ini berarti data yang disajikan pada penelitian ini layak dan baik untuk diteliti.

\section{Uji Autokorelasi}

Uji autokorelasi adalah pengujian autokorelasi dilakukan untuk menguji apakah dalam sebuah model regresi linear ada korelasi antara kesalahan penganggu pada periode $t$ dengan kesalahan penganggu t-1 (sebelumnya). Jika terjadi korelasi, maka dinamakan ada problem autokorelasi. Model regresi yang baik adalah regresi yang bebas dari autokorelasi. Uji yang digunakan adalah uji Durbin Watson dimana untuk mengetahui ada tidaknya autokorelasi dalam suatu model regresi. hasil analisis tersebut dapat diketahui bahwa Durbin Witson menghasilkan nilai sebesar 2,452. Oleh karena nilai Durbin Witson $=2,452$ lebih besar dari 1,8863 (dU) dan kurang dari 4-1,8863 (4-dU) yaitu sebesar 2,1137, maka secara statistik tersebut tidak terjadi autokorelasi pada model regresi. 


\section{Uji Simultan/ Uji F}

Uji $\mathrm{F}$ digunakan untuk menganalisis variabel permodalan, pemasaran, teknologi, strategi, spiritual quotient secara bersama-sama terhadap variabel $\mathrm{Y}$ dengan taraf signifikan 0,05 atau tingkat kepercayaan 95\%. Berdasarkan perhitungan statistik menggunakan SPSS di ketahui F-hitung adalah 23,401 dengan tingkat signifikan 0,000. Nilai signifikan F-hitung sebesar 23,401 lebih besar dari F-tabel sebesar 2,870 maka permodalan, pemasaran, teknologi, strategi dan spiritual quotient secara serentak berpengaruh terhadap kinerja. Sedangkan jika dilihat dari tingkat probabilitas sebesar 0,000 lebih kecil dari 0,005 maka permodalan, pemasaran, strategi, teknologi dan spiritual quotient secara serentak berpengaruh terhadap kinerja.

\section{Koefisien Determinasi}

Analisis koefisien determinasi digunakan untuk mengetahui seberapa besar prosentase sumbangan pengaruh variabel independen secara serentak terhadap variabel dependen. Besarnya kontribusi antara variabel permodalan, pemasaran, teknologi, strategi dan spiritual quotient terhadap kinerja pada UKM Mebel di Klaten secara bersama-sama dapat diketahui dari nilai koefisien determinasi ganda atau $\mathrm{R}^{2}$ (Adjusted $\mathrm{R}$ Square). Besarnya $\mathrm{R}^{2}$ berdasarkan hasil analisis dengan mengunakan program SPSS dapat dilihat dari tabel 1.3. sebesar 0,824. Dengan demikian besarnya pengaruh yang diberikan oleh variabel permodalan, pemasaran, teknologi, strategi dan spiritual quotient terhadap kinerja dalam UKM Mebel di Klaten 2017 secara simultan sebesar 82,4\% sedangkan sisanya 17,6\% adalah dipengaruhi oleh faktor lain yang tidak diteliti oleh penelitian ini.

\section{Parsial / Uji t}

Uji t digunakan untuk mengetahui pengaruh variabel independen yaitu permodalan, pemasaran, teknologi, strategi dan spiritual quotient secara parsial terhadap variabel dependen yaitu kinerja UKM Mebel di Klaten apakah berpengaruh secara signifikan atau tidak. Adapun hasil yang di peroleh dari pengujian terhadap variabel keuangan memiliki koefisien regresi sebesar -1,055 dengan tingkat signifikansi $0,000<0,05$. Dengan hasil tersebut menunjukkan bahwa perubahan pada variabel permodalan atau keuangan akan mengakibatkan perubahan yang negatif terhadap kinerja UKM, dan secara parsial mempunyai pengaruh yang signifikan terhadap kinerja UKM Mebel di Klaten. Sehingga dengan demikian apabila keadaan keuangan UKM turun bisa saja kinerja UKM justru bisa mengalami kenaikan. Dampak naiknya produktivitas produksi diharapkan dapat menarik pihak ketiga atau pihak luar (investor) untuk menyuntikan dananya kepada UKM tersebut. Oleh karena itu, perlu perubahan untuk mengelola keuangan sehingga tidak mempengaruhi produktivitas produksi. Modal yang dibutuhkan oleh pengrajin adalah modal kerja untuk di investasikan 
pada alat-alat berteknologi modern, di mana dampak dari penggunaan modal ini akan membantu pengrajin memenuhi kualitas yang dibutuhkan oleh eksportir yang pada akhirnya akan meningkatkan kinerja usahanya. Hasil penelitian ini sejalan dengan penelitian yang dilakukan oleh Endang Purwanti pada UMKM makanan di daerah Salatiga yang menyatakan: semakin besar modal yang digunakan dan semakin mudah untuk mendapatkan modal usaha akan mengakibatkan meningkatnya perkembangan usaha (Makarti, 2012). Pengusaha di semua bagian dunia tampaknya memiliki masalah dalam mengakses modal, mendapatkan pembiayaan, meyakinkan para bankir dan memperoleh pinjaman bank atau kredit dari pemasok. Ini sesuai dengan beberapa studi di seluruh dunia yang telah dilakukan untuk menyoroti tantangan yang dihadapi oleh pengusaha (Chowdury et al, 2013).

Hasil pengujian terhadap variabel keuangan memiliki koefisien regresi sebesar 0,768 dengan tingkat signifikansi $0,000<0,05$. Dengan hasil tersebut menunjukkan bahwa perubahan pada variabel pemasaran akan mengakibatkan perubahan yang positif terhadap kinerja UKM, dan secara parsial mempunyai pengaruh yang signifikan terhadap kinerja UKM Mebel di Klaten. Sehingga dengan demikian jika langkah didalam melakukan pemasaran naik maka kinerja UKM Mebel di Klaten juga akan mengikuti kenaikan. Hasil penelitian ini sejalan dengan penelitian yang dilakukan oleh chowdury et al (2013) pada UMKM di Bangladesh yang menyatakan: ada hubungan yang signifikan antara pemasaran dan keberhasilan pengusaha. Ada semakin banyak bukti dalam literatur bahwa masalah utama untuk UKM di negara berkembang bukan ukurannya yang kecil tetapi isolasi mereka, yang menghambat akses ke pasar, serta dukungan informasi, keuangan dan kelembagaan (Mead \& Liedholm, 1998; Swierczek \& Ha, 2003).

Hasil pengujian terhadap variabel teknologi memiliki koefisien regresi sebesar 1,544 dengan tingkat signifikansi $0,002<0,05$. Dengan hasil tersebut menunjukkan bahwa perubahan pada variabel teknologi akan mengakibatkan perubahan yang positif terhadap kinerja UKM, dan secara parsial mempunyai pengaruh yang signifikan terhadap kinerja UKM Mebel di Klaten. Sehingga dengan demikian berkembangnya penggunaan dan pemanfaatan teknologi yang moderen atau dengan mengikuti kemajuan zaman dapat berpengaruh terhadap naiknya kinerja UKM Mebel di Klaten. Hasil penelitian ini sejalan dengan penelitian yang dilakukan oleh chowdury et al (2013) pada UMKM di Bangladesh yang menyatakan ada hubungan yang signifikan antara teknologi dan kesuksesan pengusaha.

Hasil pengujian terhadap variabel strategi memiliki koefisien regresi sebesar $-1,433$ dengan tingkat signifikansi $0,005<0,05$. Dengan hasil tersebut menunjukkan bahwa perubahan pada variabel strategi akan mengakibatkan perubahan yang negatif terhadap kinerja UKM, dan secara parsial mempunyai pengaruh yang signifikan terhadap kinerja UKM Mebel di Klaten. Sehingga 
dengan demikian jika pemakaian strategi di jalankan kinerja UKM bisa saja menurun. Hal ini bisa terjadi dikarenakan pemilihan strategi yang terlalu sulit untuk dijalankan atau strategi yang salah atau kurang tepat untuk dijalankan.

Hasil pengujian terhadap variabel spiritual quotient memiliki koefisien regresi sebesar 1,052 dengan tingkat signifikansi $0,000<0,05$. Dengan hasil tersebut menunjukkan bahwa perubahan pada variabel spiritual quotient akan mengakibatkan perubahan yang positif terhadap kinerja UKM, dan secara parsial mempunyai pengaruh yang signifikan terhadap kinerja UKM Mebel di Klaten. Sehingga dengan demikian naiknya level kecerdasan yang dimiliki oleh sumber daya manusia yang dimiliki UKM dapat menaikan kinerja UKM Mebel di Klaten. Hal ini juga berpengaruh untuk mencegah resiko kesalahan didalam pemilihan strategi. Keterampilan dan latar belakang pendidikan pengusaha ini sangat penting untuk pengembangan bisnis baru. Kedua, semakin banyak pria dan wanita yang muncul sebagai pengusaha dalam ekonomi Bangladesh dengan sedikit pengalaman dan pendidikan (Chowdhury, 2011). Orang yang berpendidikan biasanya kreatif dan inovatif dan mereka selalu mencari sesuatu yang unik untuk mengisi kebutuhan atau keinginan (Ndubisi et al, 2003). Wanita yang berpendidikan dan berpengalaman lebih tertarik untuk menjadi pengusaha daripada wanita yang tidak terdidik dan tidak berpengalaman (Kavita, Anantharaman, dan Jayasingam 2008).

\section{Pengaruh Permodalan atau Keuangan, Pemasaran, Teknologi, Strategi dan Spiritual Quotient}

Setelah dilakukan pengujian secara simultan atau secara bersama-sama maka dapat diketahui bahwa antara vaeriabel dependen yaitu kinerja dengan variabel independen yaitu permodalan atau keuangan, pemasaran, teknologi, strategi dan spiritual quotient mempunyai pengaruh yang signifikan yaitu dilihat nilai signifikasi sebesar 0,000. Dan juga memiliki tingkat F-hitung sebesar 23,401 lebih besar dari F-tabel sebesar 2,870. Hal ini dapat diartikan bahwa permodalan atau keuangan, pemasaran, teknologi, strategi dan spiritual quotient mempunyai pengaruh yang besar didalam membantu meningkatkan kinerja UKM Mebel.

Setelah dilakukan pengujian secara parsial atau secara individu maka dapat diketahui bahwa antara vaeriabel independen yaitu permodalan atau keuangan, pemasaran, teknologi, strategi dan spiritual quotient terhadap kinerja UKM Mebel mempunyai pengaruh yang signifikan. Dari hasil pengujian diatas juga menyatakan hasil pengujian menyatakan positif antara permodalan atau keuangan, pemasaran, teknologi, strategi dan spiritual quotient terhadap kinerja. Hal ini dapat diartikan bahwa permodalan atau keuangan, pemasaran, teknologi, strategi dan spiritual quotient mempunyai hubungan searah dengan kinerja UKM. Sebagai contoh bila salah satu dari variabel independen mengalami peningkatan maka kinerja UKM pun akan meningkat. 


\section{KESIMPULAN}

Berdasarkan penelitian yang didapat dari variabel dependen yaitu permodalan atau keuangan, pemasaran, teknologi, strategi dan spiritual quotient dengan variabel dependen yaitu kinerja UKMi, permodalan atau keuangan, pemasaran, teknologi, strategi dan spiritual quotient terhadap kinerja UKM Mebel yang telah diamati dan diteliti maka setelah dilakukan analisis data dan uji hipotesis yang dapat ditarik kesimpulan sebagai berikut. Variabel independen permodalan atau keuangan, pemasaran, teknologi, strategi dan spiritual quotient berpengaruh positif dan signifikan pada kinerja UKM Mebel di Klaten. Jika dilihat dari nilai standardized coefficient beta, variabel independen yang berpengaruh paling dominan pada kinerja UKM Mebel di Klaten tahun 2017 adalah variabel teknologi yaitu sebesar 0,344 .

Berdasarkan nilai R square sebesar 0,824 (82,4\%), kinerja UKM Mebel dipengaruhi oleh permodalan atau keuangan, pemasaran, teknologi, strategi dan spiritual quotient dan sisanya $0,176(17,6 \%)$ dipengaruhi oleh variabel lain yang tidak dimasukkan ke dalam model. Penelitian selanjutnya dapat menambah variabel independen misalnya tingkat kepuasan konsumen, kualitas produk, dan faktor lainnya untuk mengetahui variabel-variabel apa saja yang berpengaruh terhadap kinerja UKM Mebel. UKM Mebel disarankan untuk menggunakan sarana teknologi dalam mendukung usaha yang dijalankan. Sehingga dengan adanya teknologi baik dari peralatan dan media pemasaran dapat mendukung kinerja dari UKM Mebel.

\section{REFERENSI}

Adeosun, O., Adeosun, T.H., and Adetunde, I.A., 2009. Strategic Application of Information and Communication Technology for Effective Service Delivery in Banking Industry. Journal of Social Science, 5(1), 47-51

Allison, M., dan Kaye, J. 2005. Perencanaan Strategis Bagi Organisasi Nirlaba. Yayasan Obor Indonesia. Jakarta.

Among Makarti, Vol.5 No.9, Juli 2012, Pengaruh Karakteristik Wirausaha, Modal Usaha, Strategi Pemasaran Terhadap Perkembangan Umkm Di Desa Dayaan Dan Kalilondo Salatiga (Endang Purwanti)

Chowdhury, M, \& Amin, M. (2011). The effects of human, social and financial capital on woman entrepreneurship venturing in Bangladesh, International Journal of Business and Economics Perspectives, 6(1), 138-149. 
Crittenden, W.F. and Crittenden, V.L. (2000). "Relationships between organizational characteristics and strategic planning processes in nonprofit organizations”. Journal of Management Issues, Vol. 12 No. 2.

E. Tapinos, R.G. Dyson and M. Meadows, 2005, The impact of performance measurement in strategic Planning, International Journal of Productivity and Performance Management Vol. 54 No. 5/6, Emerald Group Publishing Limited

Emma dwi ratnasari, 2016, Jurnal Riset Ekonomi Pembangunan Vol 1 no 1, Universitas tidar, Magelang.

Christea, Frisdiantara dan Mukhlis, Imam, 2016 Ekonomi Pembangunan sebuah kajian teoritis dan empiris, Lembaga Penerbitan Universitas Kanjuruhan Malang.

George, M. (2006), "Practical Applications of Spiritual Intelligence in the Workplace,” Human Resource Management International Digest. Vol. 14, No.5.

Hadiyati, E. 2010. Pemasaran untuk UMKM (Teori dan Aplikasi), Edisi Pertama, Cetakan Pertama, Bayumedia, Malang.

Hanifiyah Yuliatul Hijriah, 2016, Jurnal TSAQAFAH, Universitas Airlangga, Surabaya Vol. 12, No. 1.

Hendro, 2011, Dasar-Dasar Kewirausahaan, Penerbit Erlangga, Jakarta.

Hermana, Budi. Tanpa tahun, Mendorong Daya Saing di Era Informasi dan Globalisasi: Pemanfaatan Modal Intelektual dan Teknologi Informasi Sebagai Basis Inovasi di Perusahaan. (online) (http://bhermana.staff.gunadarma.ac.id) diakses tanggal 17 September 2017

Hodgetts, R.M. and Kuratko, D.F. (2001), Effective Small Business Management, Dryden, Fort Worth, Texas.

Jumingan, 2011, Analisis Laporan Keuangan, Cetakan ke empat, PT. Bumi Aksara, Jakarta

Kadkhoda, M., \& Jahani, H. (2012), Problem-solving capacities of spiritual intelligence for artificial intelligence. Procedia - Social and Behavioral Sciences, 32, 170-175.

Kavitha, R, Anantharaman, R, \& Jayasingam, S. (2008). Motivational Factors Affecting Entrepreneurial Decision: A Comparison between Malaysian 
Women Entrepreneurs and Women Non Entrepreneurs, Communications of the IBIMA, Volume 8

Kotler, P. (2000). Manajemen Pemasaran, edisi millennium, Jakarta: Prenhallindo

Kotler, P. and G. Armstrong. 2004. Dasar-dasar Pemasaran, Edisi Kesembilan. Jakarta:Penerbit Indeks

McCormic, D.W, 1994, Spirituality and Management, Journal Of Managerial Psychology, Vol.9, pp.5-8

Mitroff, L.I, and Denton, E,A, 1999, A Study of Spiritualty in The Work Place, Sloan Management Review, Vol.40, No.4, pp.83-92

Mohammed S. Chowdhury, Zahurul Alam, Md. Ifttekhar Arif. (2013), Success Factors of Entrepreneurs of Small and Medium Sized Enterprises: Evidence from Bangladesh, Business and Economic Research ISSN 2162-4860 2013, Vol. 3, No. 2

Ndubisi, O, Gupta, K, \& Massoud, S. (2003). Organizational Learning and Vendor Support Quality By The Usage of Application Software Packages: A Study of Asian Entrepreneurs. Journal of Systems Science and Systems Engineering 12(3), 314-331.

Nggermanto, A (2002) Quantum Quotient - Kecerdasan Kuantum, Nuansa, Bandung.

Noble, C.H. (1999), "Building the strategy implementation network (implementation is a vital and often neglected, phase of strategic planning)", Business Horizons, vol 42 no. 6 p. 19.

Noble, K. D. (2000). Spiritual intelligence: A new frame of mind. Advanced Development Journal, 9, 1-29

Pearce, John A. and Robinson Richard B. Jr. (2003). Strategic Management Formulation, Implementation and Control. Mc Graw hill, Boston

Pribadi, Fancholiq J., dan Ferdinand Andrias Mundung. 2007. Edisi 1. Manajemen Usaha UMKM (Konsep, Pengalaman Empiris dan The Best Practice). Malang: Bayumedia Publishing.

Purwanti, Endang, 2012, Pengaruh Karakteristik Wirausaha, Modal Usaha, Strategi Pemasaran Terhadap Perkembangan Umkm Di Desa Dayaan Dan Kalilondo Salatiga, Among Makarti, Vol.5 No.9, Juli 2012 
Rademakers, martijn. 2005. "Corporate Universities: Driving Force of Knowledge Innovation. ” Journal of Workplace Learning; 17, 1/2; abi/informs global. Pg 130

Sakur, 2011, Kajian Faktor-Faktor yang Mendukung Pengembangan Usaha Mikro Kecil dan Menengah: Studi Kasus di Kota Surakarta, Jurnal Spirit Publik Volume 7, Nomor 2, Universitas Sebelas Maret, Surakarta.

Stonehouse, G. and Pemberton, J. (2002), "Strategic planning in SMEs - some empirical findings', Management Decision, Vol. 40 No. 9, pp. 853-61.

Sugiono, 2015, Analisis Penyediaan Dan Penggunaan Modal Kerja Umkm (Usaha Mikro, Kecil Dan Menengah) Dalam Meningkatkan Laba Usaha Pada Kub (Kelompok Usaha Besama) Alam Lestari

Swierczek, F. W., \& Ha, T. T. (2003). Entrepreneurial orientation, uncertainty avoidance and firm performance: an analysis of Thai and Vietnamese SMEs. International Journal of Entrepreneurship and Innovation, 4(1), 4658. Depok, Prosiding Semiar Nasional Pendidikan Ekonomi \& Bisnis Fakultas Keguruan dan Ilmu Pendidikan Universitas Sebelas Maret Surakarta Sabtu, 07 November 2015

Suharyadi dkk, 2007, Kewirausahaan Membangun Usaha Sukses Sejak Usia Muda, Salemba Empat.

Supratikno, Hendrawan. 2003. Advanced Strategic Managemen: Back To Basic Approach. PT. Grafindo Utama. Jakarta:

Swastha dan Irawan, 2008. Manajemen Pemasaran Modern. Edisi 13. Penerbit Liberty, Jogjakarta

Tapinos, E., Dyson, R.G. and Meadows, M. (2005), “The impact of performance measurement in strategic planning', International Journal of Productivity and Performance Management, Vol. 54 No. 5/6, pp. 370-84.

Thompson, Arthur A. Jr, and A.J. Strickland III. 2001. Crafting and Executing Strategy Text and Readings, Twelfth Edition, Mc Graw-Hill Irwin, New York

Thompson, Arthur.A Jr. and Strickland, A.J III,2004, Strategic Management: Concepts and Cases, 12th ed, Richard D. Irwin. Inc. Company, USA

Wahyono, 2002, "Orientasi pasan dan inovasi: Pengaruhnya Terhadap Kinerja Pemasaran”, Jurnal Sains Pemasaran Indonesia, Vol 1 No. 1 Mei. 
Lasminiasih, Rooswhan Budhi Utomo, Sigit Nur Dianto Analisis pengaruh Permodalan, Pemasaran, Teknologi \& Inovasi, Kecerdasan Spiritual dan Perencanaan Strategi terhadap Kinerja Usaha Kecil Menengah (UKM) Mebel di Klaten Jawa

Zohar, D., \& Marshall, I. (2001). SQ - Spiritual intelligence, the ultimate intelligence. Jerusalem: Keter (Hebrew edition). 